\title{
The Common Destiny of Un/common Cultures
}

\author{
VINCENZO ROMANIA \\ UNIVERSITY OF PADOVA
}

\begin{abstract}
Kamala Viswewaran
Un/Common Cultures. Racism and the Rearticulation of Cultural Difference
\end{abstract} Duke University Press, Durham 2010

ISBN 9780822346357

RRP US\$23.95 (pb)

Kamala Viswewaran's book is a collection of essays she wrote while teaching at various universities in the United States. Its main focus is describing the different ways sociologists and anthropologists have used concepts such as race, culture, caste; the interdisciplinary influences and the transformation these concepts went through during the twentieth century, and their significance at a political and social level. Indeed, the objective of this intellectual effort is to construct a history of the present, in the sense of Foucault, proposing a strong critique of the rigidity of the so called new culturalism, the tendency of many scholars and opinion leaders to consider different national and religious cultures as uncommon, as a medium of alterity that prevents reciprocal understanding and sharing of experiences. Viswewaran also attempts to demonstrate the weakness of what we could call a purely cultural interpretation of social forms of exclusion and marginalisation. 
The essays consider the relationship between culture and gender; the conflict between the biological and the constructivist conceptions of race; the extension of the concept of caste to the study of racism; the relationship among cultures, states and nations; the relevance of castes in the history of Indian sociology and the recent emergence of a Dalit sociology. All these issues represent familiar elements for the author, an American anthropologist of Indian origins whose experience includes that of a second generation migrant living in Chicago, the scientific interests of her profession, and a significant involvement in the activities of social movements. Here, culture is not considered as an area of scientific inquiry but as a 'performative' with a discursive function of 'substitutions, transpositions, displacements, and reversals' (3) among the different fields of knowledge and power in which it occurs in the global scenario. Viswewaran is committed to analysing how 'objects such as "culture", "caste" or "race" circulate across and through disciplines, places, and political formations'. (4-5) In this sense, Un/common Cultures also deals with scientific cultures and their contamination.

The first and the last chapters of Un/common Cultures are devoted to a critique of feminist universalism. In both essays, gender is described as a perspective through which Western societies have constructed various kinds of 'others' as less civilised cultures. In Chapter One- “Wild West" Anthropology and the Disciplining of Gender'-Viswewaran draws a history of early women anthropologists. Analysing a series of ethnographic reports produced between the end of the nineteenth century and the first decades of the twentieth century, she demonstrates how those scholars contributed to the characterisation of native cultures as 'wild' and 'untamed'. So-called 'primitive' societies 'were thus seen to lack sex differentiation altogether, or to possess it in mere rudimentary form, prohibiting the admission of Native American and African American women into the very category of womanhood'. (23) Those reports, the author maintains, were more concerned with the foregrounding of the savagery of others than with the effects of westward conquest on the people they studied.

In Chapter Seven, considering contemporary international reports on human rights, Viswewaran maintains that 'contemporary human-rights discourse on women is one such example, producing the "female subjects of public international law" through a notion of the 'exotic other female'. (191) Here the objective of the 
author is to demonstrate that women's rights in South Asian nations cannot be divorced from the community's or the nation state's rights: 'This is also literally true in India, where a woman's civil rights are embedded in the personal laws of her community.' (203) In both topics, Viswewaran underlines how social sciences and international politics have given the wrong cultural and gendered interpretation of some situations, institutions and processes. In her opinion, this misreading of social reality has had an evident performative effect, justifying forms of scientific, political and economic imperialism.

The second topic considered is the relationship between race and culture. In Chapter 2, the author scrutinises how race was defined in the history of anthropology in contrast with the concept of culture. In particular, Viswewaran claims that the original definition of culture proposed by Boas 'has led to problems for the development of the modern anthropological notion of culture'. (56) The opposition between race and culture, in fact, has for a long time led to scientific support for the biological existence of different human races, and, at the same time, to a purely linguistic and folkloristic conception of culture: 'Although Boasian anthropology foregrounded racism as one of the most virulent problems of the times, Boas and many of his students never abandoned the belief in the value of the scientific study of race, even as they actively sought to replace race with the concept of culture or ethnic group'. (57)

Following Omi and Winant, the author suggests considering race as a construction, as a product of racism and racial conflicts themselves, a 'sociohistorical process by which racial categories are created, inhabited, transformed, and destroyed'. (69) The conflict between race and culture is a false conflict. After Du Bois, 'race is a cultural, sometimes an historical fact'. (153) The African American sociologist constitutes a reference point in the development of Viswewaran's theory. In order to support this struggle against any biological fundament of race, in Chapter Two Viswewaran introduces two writings about race by Claude Lévi-Strauss: 'Race and History' (a pamphlet commissioned by UNESCO in 1952) and 'Race and Culture' (a lecture delivered in 1971 at the behest of UNESCO and published in The View From Afar in 1985). Although the concept of race proposed by the most famous French anthropologist maintains the 'purely biological sense' stressed by Boas, the work of Lèvi Strauss is fundamental to understanding 
how savage the 'ethnocentric attitude' of Western societies is towards less developed societies.

In chapters three and four, Viswewaran underlines how important it is for the further development of anthropology to consider how sociology has used categories such as caste to understand racism in a productive way. For this purpose, a review of Du Bois', Dollard's and Myrdhal's works is proposed, as well as an analysis of ethnographic research on racial relations such as the important Deep South by Davis, Gardner and Gardner (1941). What Viswewaran intends to demonstrate with this review of American sociology is that it would be very useful to consider the caste system as a form of discrimination, in opposition to the evident attitude of denial held by Indian government in Durban during the World Conference Against Racism (WCAR) organised by the United Nations in 2001.

In Chapter Five, the topic of castes is applied to the history of Indian sociology. Here, Viswewaran denounces the Indological turn of the 1950s and the marginalisation of the plurality of cultures and religions in Indian sociology: 'casteism replicates itself at the level of both Indian society and its sociology'. (131) In analysis of articles published by the journal Contributions to Indian Sociology after 1957 , topics like caste inequality, religious pluralism and discrimination are scarcely represented. Indian sociology, committed to anti-colonialism, has continually strengthened the commonsense argument that caste divisions were merely an imperial legacy, with no effects on the present time. Instead, Viswewaran foregrounds the birth of a new Dalit sociology, highlighting the discrimination against Dalit culture in the Indian scientific and political context, and the fruitfulness of considering caste as a form of racism.

In conclusion, Viswewaran's objective in this interesting book is to limit the mainstream culturalism in anthropology and social sciences, demonstrating how social processes are governed by discourses on race and caste that are, first, scientific and political. It means that: 'anthropology (and ethnic studies) must move away from a tendency to frame communities as organic entities and to see cultures primarily as exemplars of (national or racial) differences'. (12) The book offers quite an innovative perspective, stressing the need to reconsider racism and all forms of discrimination by underlining the analogies between radically different histories of oppression with a discursive approach. An interesting effort is also devoted to 
understanding the relationships between official documents produced by international organisations and scientific debate. One criticism that could be made of the author is that of being rigidly structuralist, and consequently of underestimating the importance of discrimination and racism occurring in the interpersonal communication of everyday interaction among individuals. The dichotomy community/individual is not developed well enough in Un/Common Cultures. But, despite the attention devoted to anthropology and to macrosocial phenomena, the book offers a fresh lecture on the contemporary global scenario and could be recommended to all scholars interested in social sciences.

Vincenzo Romania is a researcher in Cultural and Communication Studies at the University of Padova, Italy. He is an editorial member of Empedocles: European Journal for Philosophy of Communication. His research activity is focused on intercultural communication, cultural studies and symbolic interactionism. 